\title{
Geografía del extractivismo: conflicto socioambiental en el Río Sambingo. Reflexiones desde la ética ambiental
}

\section{Geography of extractivism: socio-environmental conflict on the Sambingo River in southern Colombia. Reflections from environmental ethics}

\author{
Ylver Mosquera-Vallejo \\ Geógrafo. Candidato a Doctor en Geografía. Instituto de Geografía. Facultad de Historia, Geografía y Ciencia Política. Pontificia Universidad \\ Católica de Chile. Avenida Vicuña Mackenna 4860, Macul, Santiago de Chile, Chile, yamosquera@uc.cl \\ Alex Paulsen Espinoza \\ Magister en Geografía y Geomática. Candidato a Doctor en Geografía. Instituto de Geografía. Facultad de Historia, Geografía y Ciencia Politica. \\ Pontificia Universidad Católica de Chile. Avenida Vicuña Mackenna 4860, Macul, Santiago de Chile, Chile, appaulse@uc.cl
}

Recibido: 15 de julio 2019 || Aprobado: 6 de marzo 2020

Resumen

Este artículo aborda un conflicto socioambiental en el sur de Colombia resultado de la extracción ilegal de oro. El propósito en este trabajo fue reflexionar acerca del conflicto socioambiental por minería ilegal en el río Sambingo, desde la ética ambiental. Se utilizaron imágenes satelitales de dos años -2014 y 2016-, además de una entrevista y fuentes secundarias. Con ello fue posible identificar las áreas afectadas por la minería ilegal e indagar sobre prácticas de sujetos morales que se inscriben en el espacio a través de diferentes marcos ético-ambientales. Se concluye que los afrocolombianos viven bajo vínculos simbólico/materiales con su territorio, los cuales entran en conflicto con los de los mineros foráneos que llevan a cabo un extractivismo violento, en un contexto que carece de un marco ético normativo y ambiental que propicia la destrucción de la vida.

Palabras clave: Ética ambiental; Minería ilegal; Río Sambingo; Conflicto socioambiental

\section{Abstract}

This article addresses a socio-environmental conflict in southern Colombia resulting from the illegal extraction of gold. The purpose of this work was to reflect the socio-environmental conflict over illegal mining on the Sambingo River, from environmental ethics. Two-year satellite images - 2014 and 2016were used, as well as an interview and secondary sources. With this, it was possible to identify the areas affected by illegal mining and investigate the practices of moral subjects that are registered in the space through different ethical-environmental frameworks. It is concluded that Afro-Colombians live under symbolic / material links with their territory, which come into conflict with foreign miners 'ones, who carry out a violent extractivism, in a context that lacks a normative and environmental ethical framework that promotes destruction of the life.

Key words: Environmental ethics; Illegal mining; Sambingo river; Socio-environmental conflict

Cita sugerida: Mosquera-Vallejo, Y. y Paulsen Espinoza, A. (2020). Geografía del extractivismo: conflicto socioambiental en el Río Sambingo. Reflexiones desde la ética ambiental. Estudios Socioterritoriales. Revista de Geografía, (27), 043. DOI: https://doi.org/10.37838/unicen/est.07-043 


\section{INTRODUCCIÓN}

A inicios del 2016 la revista Semana publicó una nota con el título "El primer río en Colombia que desaparece por completo" (Semana, 29/01/2016), en ella alertaba acerca de los daños que había causado la extracción de oro en el río Sambingo. En este reportaje ponen a la palestra de la opinión pública, el modo en que este río fue afectado, a partir de la extracción ilegal del mineral. Igualmente, las imágenes publicadas sensibilizaron a distintos sectores de la sociedad sobre las enormes proporciones del daño que se le ha causado al río y lo que les espera a muchos otros drenajes del país de continuarse extrayendo oro mediante el uso indiscriminado y combinado de retroexcavadoras, dragas, mercurio, entre otros. Las ganancias que supuestamente obtenían mensualmente los actores ilegales que se dedicaban a esta actividad ilícita, ascendían al millón de dólares, la cual es una “(...) cifra irrisoria para el daño ambiental que causaron, y más si tenemos en cuenta que cálculos de expertos consideran que recuperar todo ese ecosistema costaría alrededor de $\$ 100.000$ millones" (USD 302 millones) (Semana, 29/01/2016).

La zona de estudio es parte en términos socioculturales y espaciales del valle del Patía (suroccidente de Colombia), debido a esto es habitada por poblaciones afrocolombianas que se asentaron ahí desde la época colonial. Estas se conformaron, por un lado, a partir de las poblaciones negras cimarronas ${ }^{1}$, que vivieron en el Palenque $^{2}$ del Castigo luego de huir de las minas de Barbacoas e Iscuandé (situadas en el actual departamento de Nariño) y de algunas haciendas del Valle de Cauca (segunda mitad del siglo XVII y primeras décadas del XVIII). Por el otro, se constituyeron a partir de las poblaciones es-

1 Se denomina cimarronaje al conjunto de prácticas insurrectas que permitieron a los negros diseñar estrategias de autoprotección, desafiar al sistema esclavista y desarrollar diferentes prácticas de organización. Esto sirvió para que estas comunidades encontraran su autonomía como sujetos y formas de autosustento familiar.

2 Los Palenques eran aquellos lugares de difícil acceso en los que los esclavos, huidos de las minas y haciendas, se organizaban económica, social y políticamente. clavizadas que fueron incorporadas en el desarrollo de diversas actividades en las haciendas $y$ minas instaladas en el área hacia el siglo XVIII (Zuluaga, 1993). Ellas hicieron de estas planicies, ríos y selvas su propio hábitat y estructuraron un modo de vida a partir de unas prácticas culturales definidas. A su vez, construyeron un conjunto de imaginarios y experiencias espaciales de diferenciación, mediante los cuales configuraron una identidad territorial distinta a la de otras poblaciones negras que habitaban y habitan otros lugares de la geografía colombiana (Mosquera-Vallejo, 2018).

La siguiente contribución tiene por objetivo reflexionar sobre las consecuencias socioculturales, espaciales y ambientales de la extracción ilegal de oro que comenzó a suceder a partir del año 2013 en uno de los sectores del río Sambingo hasta el 2016. La población circundante se vio afectada de diversas maneras con la alteración del cauce del río y la manipulación de este con maquinaria pesada y otros elementos. No obstante, esto también nos llevó a (re)pensar las relaciones entre sociedad y naturaleza. A partir de un marco ético ambiental, se reflexionó sobre aquellas miradas antropocéntricas acerca de la naturaleza que han legitimado procesos de extracción de los recursos naturales, sin ningún tipo de consideración social y ecológica. Hoy en día, esto se ve entrelazado con un capitalismo en su fase neoliberal que se encuentra en constante expansión y extracción de recursos naturales, pero, sobre todo, en la influencia que este sistema ejerce en algunas poblaciones para entablar relaciones utilitaristas con el entorno.

Metodológicamente, este trabajo se basó en el análisis e interpretación de información documental sobre conflictos socioambientales, ética y justicia ambiental. Igualmente, se utilizaron fuentes oficiales como los informes de la autoridad ambiental en los que se detalla acerca de las consecuencias ecológicas y socioculturales de este conflicto socioambiental. Paralelamente, se elaboró cartografía temática del conflicto y fue realizada una entrevista semiestructurada a un líder social afrodescendiente de la zona. 
Como resultado de esta estrategia metodológica, inicialmente se puso de relieve el proceso que llevó al río Sambingo a ser objeto de extracciones mineras que dieron lugar a un conflicto socioambiental. En este sentido, presentamos el cuándo, cómo y qué consecuencias trajo el conflicto socioambiental para los afrocolombianos que habitan los alrededores del río. Luego exponemos los principios que guían el marco ético propuesto desde la ética ambiental, para después explicitar la metodología. Enseguida, iniciamos un proceso de análisis y lecturas, basados en las nociones de justicia ambiental y distribución ecológica, en tanto categorías analíticas para construir un marco ético ambiental y pensar desde ahí el conflicto socioambiental en el río Sambingo. Este proceso nos llevó a una serie de reflexiones, a partir de las cuales se establece que están en disputa dos visiones o formas de ver el mundo completamente diferente. En primera instancia, la de los afros construida con base en experiencias históricas y espaciales, articuladas a partir de entramados socionaturales entre las poblaciones locales y el río Sambingo. En segunda ins- tancia, y en contraposición a la anterior estaría desplegada la mirada agenciada por los mineros, quienes únicamente ven usos utilitaristas en el río. Por último, presentamos unas consideraciones finales que articulan algunos elementos de los resultados e interpretaciones a partir de las categorías de análisis trabajadas.

\section{Obertura: minería ILEGAL en el RÍO SAmbingo}

La zona de estudio se encuentra localizada en Colombia, específicamente en el sector sur del Departamento del Cauca, entre los municipios de Mercaderes y Bolívar, los cuales se encuentran ubicados entre los $1^{\circ} 47^{\prime} 43^{\prime \prime}$ latitud norte y los $77^{\circ} 9^{\prime} 55^{\prime \prime}$ longitud oeste; mientras que el segundo municipio entre los $1^{\circ} 50^{\prime} 09^{\prime \prime} \mathrm{de}$ latitud norte y entre los $76^{\circ} 57^{\prime} 59^{\prime \prime}$ de longitud oeste. El río Sambingo es parte de la cuenca hidrográfica del Patía, siendo este tributario del río Patía, junto a otros como: los ríos Guachicono, Esmita, Bojoleo y Mayo. En tal sentido, la subcuenca del río Sambingo se encuentra localizada entre las coordenadas $1^{\circ} 55^{\prime} 17^{\prime \prime}$ latitud norte y los $77^{\circ} 06^{\prime} 26^{\prime \prime}$ longitud oeste, teniendo cerca de $56.579 \mathrm{~km} 2$ (Figura 1).

Figura 1. Localización del departamento del Cauca y el Río Sambingo

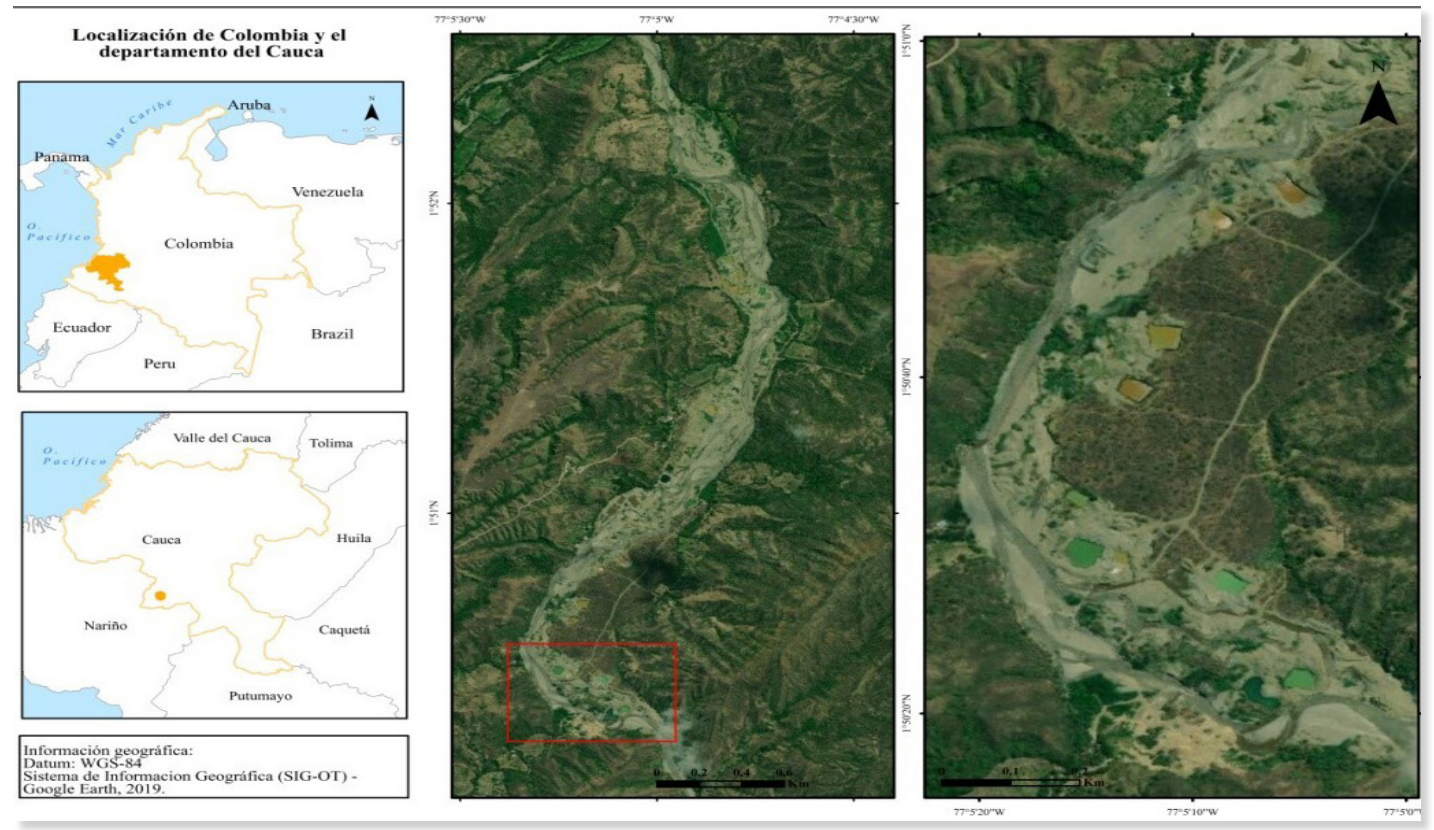

Fuente: elaboración personal con base en Google Earth (2019) 
A comienzos del año 2012, concretamente al río Patanguejo, llegaron las primeras máquinas retroexcavadoras para la extracción ilegal de oro. Como resultado de las presiones del Consejo Comunitario ${ }^{3}$ de la zona, estas máquinas fueron retiradas. Esto sería el comienzo de un conflicto que pronto adquiriría mayores dimensiones, pues en el año 2013 el interés de los mineros se centró en otro afluente cercano: el Sambingo, este río nacido en una ecorregión conocida como el Macizo colombiano, fue objeto de extracción ilegal de oro ${ }^{4}$ durante cuatro años por parte de mineros externos o foráneos como afirma la gente nativa. Los efectos socioambientales (esto es, elementos socioculturales, económicos y biofísicos interactuando), como consecuencia de la explotación minera fueron múltiples, ya que este conflicto agenció otro tipo de conflictividades. En términos socioculturales, una de las consecuencias de la minería ilegal fue la restricción en la movilidad espacial, sobre todo para algunos líderes y autoridades civiles que se oponían al desarrollo de la explotación ilegal de oro. Así, por ejem-

3 Los consejos comunitarios de comunidades afrodescendientes son organizaciones de base que funcionan como figuras políticas y territoriales creadas a partir de la Ley Nacional 70/1993, que tienen como función las de administrar las tierras colectivas de estas comunidades y velar por la preservación de la identidad cultural, la conservación de los recursos naturales, entre otros.

4 De acuerdo con un informe de la Corporación Autónoma Regional del Cauca -CRC-, el proceso de extracción del oro se daba de la siguiente manera "la actividad minera se realizaba usando un sistema que consistió en la desviación del cauce natural del rio Sambingo, esta actividad la realizan para poder extraer el material mineralizado que queda al descubierto por donde corría antes la fuente hídrica, utilizando maquinaria pesada (retroexcavadora de cuchara montada sobre una oruga). Debido a la concentración o aumento en el rendimiento de estos sitios, se empieza a profundizar haciendo uso del brazo hidráulico y la cuchara, se extrae material mineralizado para posteriormente ser lavado en la superficie sobre la margen protectora del rio, donde se utilizan las diferentes clasificadoras metálicas tipo $Z$ hasta de cinco metros de altura, donde el material es depositado en la parte más alta de ésta y se le inyecta chorro de agua a presión para empezar a lavar el material y separar el metal precioso gracias a la diferencia de densidad o peso específico, el cual queda retenido en la base inferior debajo de las rejillas, estas se encuentran asentadas en varias capas de costalillas de fibra o fique donde queda atrapado el material útil” (CRC, 2016, p. 4) plo, informes técnicos de la Corporación Autónoma Regional del Cauca ${ }^{5}$-CRC de ahora en adelante-, de la zona donde se estaba haciendo la explotación para el año 2015, sostienen que cuando se acercaron al área para hacer la evaluación ambiental, sufrieron:

Agresiones verbales e intimidaciones mientras se encontraban en Mercaderes ${ }^{6}$, donde personas extrañas les manifestaron que por seguridad no se acercaran a los sitios donde se estaba haciendo la extracción ilícita de oro en el Río Sambingo. (CRC, 2016a, p. 2)

En el caso de las poblaciones afrodescendientes, algunas de las dinámicas organizativas fueron perdiendo fuerza. Según Pedro ${ }^{7}$, uno de los líderes afrodescendientes de la zona, al río:

iban personas foráneas con sus máquinas y empezaban a lavar su oro en el río, contaminando el agua. Y eso tuvo algunas consecuencias nefastas para la gente negra (...) con la llegada de la minería fue desapareciendo el tema organizativo afro, puesto que cualquier reunión que se hiciera, las personas que estaban haciendo su ejercicio de minería ilegal, miraban los liderazgos como su amenaza (...) empezaron a amedrentar a los liderazgos, la gente se llenó de miedo y no siguió participando de las actividades, los líderes no bajaban más al territorio, porque corrían riesgos sus vidas. (Pedro, comunicación personal, corregimiento El Pilón)

La minería que se desarrolló en el Sambingo es aluvial o también conocida como depósito del placer. Esta se trata de:

una acumulación de mineral valioso que se encuentra depositado con sedimentos en el lecho de una corriente de agua o en una zona inundable. Se usan excavadoras, dragas o bombas hidráulicas (en el proceso de minado 'minería hidráulica) para extraer el mineral. La explotación minera del placer por lo general tiene por objetivo retirar oro de los sedimentos o arena aluvial de un río o corriente de agua y en zonas inundables. Debido a que la explotación minera del placer generalmente ocurre en el lecho de una corriente de agua superficial, este es un tipo de minería es ambiental-

5 Esta entidad corresponde a la autoridad ambiental en el departamento del Cauca.

6 Esta corresponde a la municipalidad donde se realizó la extracción ilegal de oro. Sin embargo, al momento de las intimidaciones a los funcionarios públicos, ellos se encontraban en la zona urbana y la minería ilegal se desarrolló en el área rural.

7 El nombre real del entrevistado ha sido cambiado para proteger su integridad y derecho a la privacidad del testimonio. 
mente destructiva, libera grandes cantidades de sedimento, y puede impactar las aguas superficiales a lo largo de muchas millas (o kilómetros) de distancia del lugar de la mina. (ELAW, 2010, p. 5)

Otra consecuencia sociocultural, consistió en el incremento de problemáticas asociadas al consumo de alcohol. " $i$ Trescientas canastas" ${ }^{8}$ de cerveza se tomaban cada semana!” Decía sorprendido un funcionario local de la CRC. El consumo de drogas, así como el aumento del costo de vida resultado del incremento en la demanda de servicios y productos por parte de los mineros hizo que hubiese inflaciones que terminaron arrastrando a aquellos dedicados a la agricultura como forma de subsistencia a la minería ilegal. En este contexto, y debido a que es un área seca donde se sufre por alimentos y agua en la época de sequía, esto facilitó para que algunas jóvenes cayeran en la prostitución.

De acuerdo con el líder entrevistado "Las niñas de la comunidad (...) con otras formas de presión, como el ofrecimiento de dinero, estos mineros se llevaban las niñas a vivir con ellos o les ofrecían unas condiciones mínimas en este caso de dinero o comida" (Pedro, comunicación personal, El Pilón-Mercaderes). Estas situaciones, llevaron a un quiebre en las dinámicas socioculturales de las poblaciones afrodescendientes asentadas históricamente en el área donde se hacía la explotación minera. La afectación al río no solo estaba causando daño

8 Una canasta tiene 30 cervezas. Si bebían trescientas por semana sería el equivalente a 9.000 cervezas cada semana. al drenaje, la flora y fauna nativa, sino además al modo de vida de los afrodescendientes de la zona. La minería estaba transformando radicalmente el paisaje, y a su vez, en términos económicos, había cambiado la dinámica productiva de la zona. Familias cuya actividad principal había sido la agricultura, especialmente la siembra de maíz, se vieron forzados a entrar a hacer minería ilegal. Sin embargo, ellos debían esperar a que las maquinas terminaran de triturar todo el material que habían sacado del río, y una vez habían hecho todo esto, lo que sobraba era lo que les correspondía a estos nuevos mineros (Figura 2).

Durante los recorridos los funcionarios de la CRC anotan en sus informes que observaron la "apertura de una vía de 10 kilómetros para el acceso directo al río Sambingo, afectando flora nativa de la zona (...) Dicha vía conduce hacia al río Patanguejo el cual debe atravesar para continuar con el recorrido" (CRC, 2016a, p. 3). Igualmente, se apreció que:
La actividad minera generó modificación del cau- ce del río por la construcción de trinchos obsta- culizando el flujo normal de la corriente, afecta- ción al lecho del río y desestabilizando los niveles de la lámina de agua de la fuente como su misma hidráulica, así como la retención del material de arrastre, modificación en los márgenes del río y sus zonas de inundación, aumentos en las cargas de sedimentos, acumulación de material removi- do, socavamientos en la base de los taludes en algunos sectores y tramos del río lo cual genera la desestabilización del mismo. (CRC, 2016a, p. 4)

Figura 2. Minería Aluvial en el río Sambingo
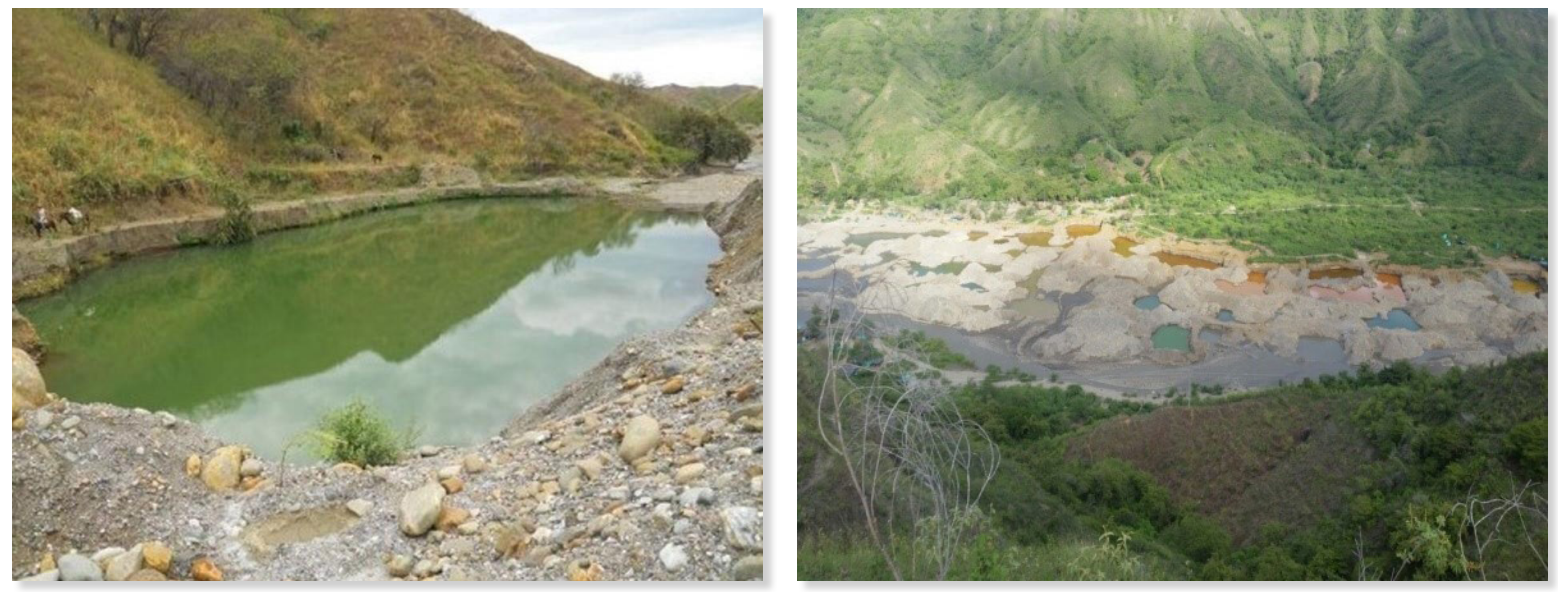

Fuente: CRC (2016a) 
Es importante destacar que, como consecuencia de la actividad minera, no solamente la gente que vive a los alrededores donde se hizo la extracción minera sufrió las consecuencias de ello. Las altas concentraciones de sustancias químicas, especialmente de mercurio, afectó dinámicas de la vida cotidiana de las poblaciones afrodescendientes que viven aguas abajo. De acuerdo con Pedro:

En la parte de más abajo, en las veredas aledañas, todo el tema de enfermedades de piel por el uso del agua, y por el consumo, otras enfermedades gastrointestinales (...) $Y$ pues también amenazas, porque acá llegaban muchos comentarios, pasaban grupos, y decían que si la gente de acá de Galíndez y El Pilón, se estaban oponiendo a la minería, ellos tenían cómo hacerse respetar, que no se fueran en contra de ellos, porque no sabían lo que nos corría pierna arriba. Entonces, si hubo amenazas, la cosa estuvo bastante afectada por la situación de salud y de seguridad. (...) En Mercaderes (el área urbana del municipio), también hubo aumento en el costo de la comida y la gente hace el mercado ahí, y pues eso se si sintió en todo el territorio. (Pedro, comunicación personal, corregimiento El Pilón)

De acuerdo con lo que se puede interpretar de lo que sostiene nuestro interlocutor, el efecto de la minería no es puntual, este se extiende por un área geográfica y desestructura modos de vida. Esto es, sistemas de relaciones sociales, formas de usar y generar el espacio, asimismo, vehiculiza cambios en las formas de ser y pensar, especialmente en los pobladores más jóvenes. De hecho, y de conformidad con lo manifestado por parte de los habitantes a los funcionarios de la CRC durante sus visitas en el año 2016:

Antes de que la actividad minera iniciara, las aguas del río Sambingo permitían a la comunidad abastecerse para sus actividades domésticas, agrícolas para el riego de diferentes cultivos y pecuarias como abrevaderos para el ganado. En el río se podían encontrar variedad de peces como el Barbudo, Sábalo y Corroncho que suplían las necesidades alimenticias de los nativos. Como consecuencia de la actividad minera, la población de peces disminuyó considerablemente, y la que se mantiene en el río posiblemente no sea apta para consumo humano debido a la bioacumulación de metales pesados, en sus organismos, entre ellos mercurio. (CRC, 2016b, p. 21)

En un intervalo de tres años, se arrasó de forma indiscriminada con los hábitats de la fauna nativa, la flora, asimismo los "afros asentados sobre la zona de influencia de la afectación ambiental, cambiaron sus labores agrícolas para dedicarse a la extracción de oro sobre el río Sambingo, lo que generó un alza en los precios de los alimentos" (CRC, 2016b, p. 21). La conclusión a la que llega uno de los informes de la CRC es lapidaria, en tanto que:

La extracción ilegal de oro sobre el río Sambingo causó una afectación CRÍTICA sobre los recursos naturales agua, suelo, flora y fauna, en donde cerca de 2000 personas trabajaban mediante el uso de maquinaria pesada (retroexcavadoras), motobombas, mangueras de diferentes pulgadas, dragas y clasificadoras para el beneficio del oro (CRC, 2016a, p. 7) (mayúscula negrita en el original)

Lo señalado hasta aquí, esto es, los informes de la autoridad ambiental en sus visitas a campo, junto con el relato del líder afrodescendiente, permiten crearnos un diagnóstico acerca del cuándo comenzó, cómo se desarrolló la actividad y qué consecuencias trajo esto para la comunidad y el entorno. El antes de la actividad minera que le subraya la comunidad a los funcionarios de la CRC, sugiere que esta es un área en la cual, la gente se interrelacionaba con su entorno, a partir de un conjunto de formas de construir su espacialidad, que les habían permitido elaborar unas experiencias conceptualizadas de su ámbito geográfico. Dichas experiencias, permitían la sostenibilidad espacio/temporal del ecosistema, pues la "organización y sus prácticas tradicionales de producción evidenciarían una particular lógica cultural garante de la conservación ambiental" (Restrepo, 2013, p. 221).

En carta enviada desde las organizaciones afrodescendientes al entonces presidente de Colombia Juan Manuel Santos, ellas sostenían que "Las comunidades afrodescendientes de Mercaderes y en específico de la región del río Sambingo, han tenido durante más de 400 años la custodia ancestral del territorio, logrando un relacionamiento respetuoso y sostenible en él" (Consejo Comunitario Fe y Esperanza, 2016, p. 1). Sin embargo, la llegada de agen- 
tes "externos con fines de explotación minera, como es sabido y documentado, ha generado serias y negativas afectaciones socioculturales y ambientales vulnerando los derechos de la comunidad y poniendo en riesgo la vida de sus integrantes y el territorio mismo" (Consejo Comunitario Fe y Esperanza, 2016, p. 1).

De tal suerte, y como consecuencia de lo anterior, "la desaparición del río Sambingo, profundiza la carencia de agua para la vida y la producción agropecuaria y con ello las dificultades para la generación de ingresos en una región históricamente afectada por condiciones de sequía" (Consejo Comunitario Fe y Esperanza, 2016, p. 1). En definitiva, esto supondría, que las experiencias de las poblaciones afrodescendientes han implicado en este territorio, formas de practicar e imaginar la naturaleza rompen con el antropocentrismo y configurarían espacios en virtud de la lógica del hombre-en-la-naturaleza y no del hombre-y-naturaleza (Etxeberria, 1994). En contraposición a ello, el extractivismo minero, representaría una modalidad de relacionamiento con el entorno, en donde se busca el lucro sin ningún tipo de consideración ética ambiental.

JUSTICIA AMBIENTAL Y DISTRIBUCIÓN ECOLÓGICA: REFLEXIONES PARA UN MARCO ÉTICO DE LOS CONFLICTOS SOCIOAMBIENTALES

La ética despliega los conceptos y los argumentos que permiten comprender la dimensión moral de las personas. La moral ofrece orientaciones para la acción, es decir, para las prácticas, esto es, aquello que hacemos y decimos en nuestras cotidianas maneras de interacción social. El marco ético en el que nos proponemos realizar este trabajo es desde la ética ambiental. En ella se considera las relaciones éticas entre el ser humano y el medio ambiente. Dicha relación analiza desde un punto de vista racional, los problemas morales relacionados con el medio ambiente (Marcos, 2011).

La confluencia entre ética, moral y naturaleza es una relación un tanto distante y problemática. Hacia fines de la década de 1940 Aldo Leopold se propone construir una ética de la tierra, considerando la ampliación ontológica del concepto de comunidad moral, a partir de la inclusión de otros seres no humanos al interior de esta (Leopold, 2007). La extensión de esta comunidad implica un balance moral entre el ser humano y la naturaleza, ya que la constitución paritaria de ambos obligaría al ser humano a cambiar sus prácticas e intervenciones sobre ella. De conquistadora y transformadora, nuestra consciencia debería pasar a considerar a la physis como un sistema con derechos propios. A pesar de los tempranos vaticinios de Leopold, la crisis ecológica se ha instalado para quedarse en la actualidad.

Según Etxeberria (1994), la actual crisis ecológica ha develado una relación moral con la naturaleza, a partir de la utilización de la técnica de manera desmedida. Dicha manera de intervenir en el estado natural de las cosas ha estado legitimada bajo los principios cartesiano-mecanicistas de dominación que se inauguran durante la modernidad, y que refuerzan las ideas antropocéntricas de dominación (Etxeberria, 1994). De esta manera, las concepciones sobre la relación sociedad-naturaleza han estado marcadas por la discusión sobre la racionalidad de seres vivos no humanos y sus sentimientos, pasando por la reflexión sobre si son sujetos de derecho hasta su constitución igualitaria con el ser humano (ecoética zoocéntrica; ecoética antropocéntrica; ética ecocéntrica) (Etxeberria, 1994).

Igualmente, en la tradición aristotélica aparecen algunas ideas que lo hacen prometedor para la ética ambiental. Ellas son la superación de los dualismos, que se podría lograr a partir de las nociones de verdad práctica donde salva la distancia entre lo objetivo y lo subjetivo. La caracterización del ser humano como animal racional político, donde articula libertad, cultura y sociedad con naturaleza. La unidad del viviente, cuerpo, alma, potencia y acto, pero una misma y única sustancia; la antropología integradora y realista, en la cual se sostiene que el ser humano es inteligencia deseosa o deseo inteligente. La integración de estos dos términos debe hacerse sin que ninguno de los dos tenga que adecuarse 
violentamente al otro (Marcos, 2011).

Otro énfasis en el cual podríamos enmarcar a la ética ambiental es a partir de las nociones de complementariedad entre la ética medioambiental y la ética dialógico social. Estas dos encuentran "consensos a partir de la idea de que una sociedad justa solamente es posible con una justicia natural y, a la inversa, una naturaleza equilibrada solamente es posible con la justicia social" (Gómez-Heras, 2005, p. 31). Desde esta perspectiva de análisis, "reconocer múltiples valores de la ética medioambiental implica superar el subjetivismo moral de matriz antropocéntrica para recuperar no solamente valores sociales, sino también valores medioambientales" (Gómez-Heras, 2005, p. 31).

Dentro del contexto de la ética ambiental surgen principios que nos pueden orientar para conformar marcos normativos que cautelen nuestras acciones; nos referimos al principio de precaución y el principio hacia las generaciones futuras. El primero de ellos definido y establecido por De Cózar (2005), quien sostiene que se deben considerar las siguientes variables: existe una amenaza de riesgo o peligro; este peligro se produce en un contexto de incertidumbre científica; y la acción para prevenir el riesgo o en tal sentido establecer un mecanismo de protección del bien que se encuentre bajo una alta probabilidad de daño (De Cózar, 2005). Este principio tiene por objetivo establecer un puente entre la información, los tomadores de decisiones y la técnica. Con ello, se pretende armonizar las políticas públicas y las acciones de privados con sus proyectos sobre el medio ambiente.

Por su parte, Riechmann (2003a) nos interpela con el objetivo de hacernos ver que el futuro $y$ sus escenarios son inciertos frente a las acuciantes acciones del ser humano frente a la naturaleza. Bajo estas ideas, es que las generaciones futuras deben ser consideradas como sujetos morales visibles, frente a la constante depredación de nuestros espacios de habitabilidad. Con ello, Riechmann introduce el concepto de principio de igualitarismo diacrónico, el cual se fundamenta en que los intereses que se deben conside- rar moralmente cuentan lo mismo, soslayando el momento temporal en que vivan los portadores de esos intereses (Riechmann, 2003a).

En este último enfoque ubicamos al concepto de justicia ambiental. Este surge en Estados Unidos en la década de 1970 como una manifestación de la nueva dirección que toman los grupos ambientalistas. Para esa época estos movimientos cambian su línea históricamente dirigida hacia la conservación de los ecosistemas, por una preocupación vinculada a los grupos vulnerables de la sociedad y su calidad de vida. Se parte de reconocer que estos grupos han sido afectados por la contaminación, y la depredación de los recursos naturales en los lugares que viven. De este modo, se inicia un movimiento por la justicia ambiental cuyo objetivo es obtener una distribución más equitativa de las cargas y beneficios ambientales (Hervé, 2010).

La justicia ambiental podría asociarse con la diversidad de prácticas y a la participación de la pluralidad de voces actuantes en la defensa de formas de vida, derechos y bienes comunes frente a la desigual distribución de la riqueza y la contaminación. Esto lleva a pensar que el concepto de justicia ambiental se ha consolidado a través de diversos procesos y elementos que han acaecido, en momentos y lugares concretos. Las prácticas racistas a las que históricamente se han visto sometidas las poblaciones subalternizadas en Estados Unidos, y Latinoamérica, los han convertido no solo en víctimas de la injusticia social, sino también en los que padecen los efectos de la contaminación (Bellmont, 2012), es decir, víctimas de las injusticias ambientales. Estas tienen un elemento inherente a ellas, que es la incompatibilidad de intereses en torno a la apropiación de los recursos.

La justicia ambiental desde ciertas perspectivas de análisis presenta tres principios básicos; el principio de sustentabilidad, el principio de partes iguales y el principio de mitad y mitad. Con respecto al primero, se argumenta que la sustentabilidad es el principio básico, para una justicia ecológica o ambiental intergeneracional (Riechmann, 2003a). De acuerdo con lo ante- 
rior, se argumenta que los sistemas económico-sociales, deben ser reproducibles sin deterioro de los ecosistemas sobre los que se apoyan. Esto significa que sustentabilidad, es viabilidad ecológica. De acuerdo con esto, las actividades humanas no deben sobrecargar las funciones de la naturaleza, ni deteriorar la calidad ambiental del mundo. Esto implica dos condiciones: respetar los límites, en otras palabras, no sobre utilizar la naturaleza y pensar en el mañana (Riechmann, 2003a; Lecaros Urzúa, 2013).

El segundo principio, es el de partes iguales. Este hace referencia a la igualdad. Tal como Riechmann sostiene, "iguales porciones de espacio ambiental para todos y cada uno de los seres humanos. Que cada habitante de la Tierra tenga igualdad de derechos al patrimonio natural de ésta" (Riechmann, 2003a, p. 8). El tercer y último principio, que es de la mitad y mitad, básicamente se refiere a la idea de materializar, es decir, de ceder espacio para otras naturalezas no humanas (Riechmann, 2003a). Por ejemplo, la ampliación de parques naturales, reservas ecológicas, entre otras. Esto significa que el mismo espacio que ocupamos los humanos, también lo puedan ocupar los no humanos, y que todos podamos coexistir con justicia dentro de una biosfera armónica. De los principios subrayados, destacaríamos para nuestro análisis sobre la minería ilegal en el río Sambingo el de sustentabilidad, en tanto que implica una dimensión espacial y temporal.

El principio de sustentabilidad en tanto eje de análisis de la justicia ambiental tiene que ver con la "distribución de bienes y males ambientales entre los seres vivos (humanos o no) tanto sincrónica, como diacrónicamente" (Riechmann, 2003b, p. 109). En ese sentido, y siguiendo a Riechmann:

(...) la idea de la diacronía nos remite de inmediato a la importante noción de sustentabilidad. En esencia, el contenido de esta noción es el siguiente: los sistemas económico-sociales han de ser reproducibles - más allá del corto plazo- sin deterioro de los ecosistemas sobre los que se apoyan. Es decir, sustentabilidad es viabilidad ecológica: los sistemas socioeconómicos que funcionan destruyendo su base biofísica son insostenibles. Dicho de otra manera: las actividades humanas no deben sobrecargar las funciones ambientales, ni deteriorar la calidad ambiental de nuestro mundo. (Riechmann, 2003b, p. 109)

Los alcances de la definición establecida hasta aquí son ajustados a los propósitos de la reflexión que estamos realizando. En efecto, el deterioro presentado sobre la base biofísica como consecuencia de la extracción de oro en el río Sambingo ha configurado un nuevo paisaje, que es la expresión de prácticas morales desplegadas por mineros de otras regiones de Colombia, que se anclan en ontologías-mundos o formas de interactuar y relacionarse con la naturaleza basadas en el afán de lucrarse sin ningún tipo de consideración sobre el entorno. Desde este punto de vista, resulta acertado establecer puentes teóricos con la ecología política y uno de sus énfasis conceptuales, que es la distribución ecológica.

Si bien a este campo teórico-práctico denominado ecología política en palabras de Enrique Leff, "conciernen no sólo los conflictos de distribución ecológica, sino explorar con nueva luz las relaciones de poder que se entretejen en los mundos de vida de las personas y el mundo globalizado" (Leff, 2003, p. 18). Esto nos lleva a pensar que esta se encuentra permeada por diferentes disciplinas; la interdisciplinariedad, la transdisciplinariedad, y de manera análoga de paradigmas que tienen distintas densidades, énfasis conceptuales y que dan lugar a diferentes problemáticas. Nos interesa hacer hincapié en el concepto distribución ecológica en el siguiente sentido:

El concepto de distribución, a mi manera de ver, es útil para unir la diversidad, el conflicto y la igualdad de acceso. Sin embargo, para hacerlo, la distribución debe abordarse desde la perspectiva cultural, ecológica y económica. La dimensión cultural permite neutralizar la tendencia penetrante de reducir todo a lo económico; la ecológica resulta fundamental puesto que los temas sobre acceso y control de los recursos naturales no son sólo aspectos centrales de muchos problemas y luchas actuales, sino que además resaltan concepciones y prácticas culturales contrastantes de la naturale- 
za, y porque las crisis ecológicas tienden a ser crisis

generalizadas. (Escobar, 2005, p. 125)

Dadas las anteriores consideraciones, la justicia ambiental, o para ser más precisos el principio de sustentabilidad en tanto uno de los pilares sobre los cuales ella se sostiene, y la articulación analítica con la idea de distribución ecológica ofrecen los insumos a partir de los cuales es posible reflexionar sobre el conflicto socioambiental por extracción minera ilegal de oro en el río Sambingo en el sur de Colombia en el periodo 2013 a 2016.

\section{APUNTES METODOLÓGICOS}

Los materiales y métodos que se han utilizado en esta investigación se encuentran apoyados en los Sistemas de Información Geográfica (SIG) e información censal oficial rescatada desde el Departamento Administrativo Nacional de Estadística (DANE). Para el caso de los Sistemas de Información Geográfica se utilizó ArcGis 10.3 para el procesamiento de las imágenes satelitales y la elaboración de la cartografía. Los métodos utilizados para el análisis de las imágenes satelitales estuvieron dados por la aplicación de herramientas para medir perímetros y áreas. De esta manera se han considerado dos imágenes satelitales de los años 2014 y 2016. Estos años fueron seleccionados a partir de que las autoridades de estos municipios identifican actividades ilegales hacia el año 2015. Por lo tanto, resulta importante considerar estos años, ya que nos permitieron constatar las intervenciones ilegales realizadas.

En términos documentales o de fuentes secundarias, se han utilizado registros de prensa y fuentes secundarias relacionadas a informes técnicos elaborados por la Corporación Autónoma Regional del Cauca. Estos informes fueron solicitados por el Municipio de Mercaderes, mediante el oficio $N^{\circ} 7049$ del 11 de septiembre del 2015. En dicho oficio, la municipalidad antes mencionada, "manifiesta la existencia de afectaciones en la cuenca del río Sambingo, causados por la explotación ilegal de minería aurífero aluvial" (CRC, 2016a, p. 1). A partir de este oficio elevado por el municipio, la CRC elaboró una serie de informes técnicos que contienen las evaluaciones realizadas por un grupo de profesionales relacionados a la ecología, ingenieria en minas y forestal.

La información extraída desde las imágenes satelitales y fuentes documentales finalmente fue complementada con una entrevista realizada a un actor clave de la zona, es decir, a un líder afrodescendiente del área afectada por la minería ilegal. Esta entrevista fue semi-estructurada y el objetivo de ella fue rescatar las formas en que la población afro fue afectada por esta situación.

CONFLICTOS SOCIOAMBIENTALES: ENTRE LA SUSTENTABILIDAD Y EL TERROR

Los conflictos socioambientales se vinculan al alto grado de transformación de las bases naturales y sociales del planeta. Estos conflictos, han aumentado su intensidad y logran articular una multiplicidad de temáticas, tanto sociales como ambientales o biofísicas. Esto ha traído como resultado la demostración de las limitaciones de varias de las herramientas teóricas para entender los conflictos, en especial, estos denominados socioambientales (Gudynas, 2010).

Los estudios sobre cuestiones socioambientales han cobrado una enorme importancia en las últimas décadas, debido a que dichos conflictos se han extendido a muchos países. En los antecedentes que abordan esta temática, encontramos diferentes enfoques. En este apartado se destacarán tres aproximaciones distintas a la cuestión socioambiental, con resultados interpretativos disímiles. Primero, al post-materialismo, procedente de la sociología política de occidente, es decir, de los países de Europa y América del Norte, en donde indagan el surgimiento de fenómenos asociados a movimientos verdes, partidos verdes, entre otros, como el efecto de una transformación en los valores de las sociedades occidentales (Walter, 2009). Una segunda aproximación, es generada en la ecología política y la economía ecológica. En ellas, se identifica en los movimientos del sur una defensa de los espacios necesarios para la vida 
(Walter, 2009; Escobar, 2005; Martínez-Alier, 2002; Gudynas, 2010). La tercera, reúne a varios pensadores que reflexionan sobre los conflictos socioambientales, en tanto procesos que son producto de una particular relación entre la naturaleza y la cultura (Walter, 2009; Muradian, Martinez-Alier y Correa, 2003).

En concreto, por conflicto socioambiental se entiende desde esta perspectiva a:

(...) procesos interactivos entre actores sociales movilizados por el interés compartido en torno a los recursos naturales, como tales: son construcciones sociales, creaciones culturales, que pueden modificarse según cómo se los aborde y se los conduzca, según cómo sean transformados y según cómo involucren las actitudes e intereses de las partes en disputa (...). La disputa por el acceso, uso y conservación de los recursos naturales suele ser una de las causas más importantes de este tipo de conflictos que están acompañados por contextos de alta inestabilidad y turbulencia que presentan en la mayoría de los casos bajos índices de desarrollo. (Spadoni, 2017, p.1)

Los conflictos socioambientales se articulan analítica y empíricamente con la idea de distribución ecológica y el principio de sustentabilidad de la justicia ambiental. El haz de relaciones que se establecen entre estas tres categorías permite ir deshilvanando el modo en que se configura, define y produce la extracción de oro en el río Sambingo (sur de Colombia). Desde esta perspectiva, afirmamos que elementos sociales, espaciales, ecológicos y temporales, así como la desigualdad en la distribución espacial y social de los impactos medioambientales negativos (Arriaga y Pardo, 2011), se entretejen, a partir de diferentes interacciones entre distintos agentes sociales en el espacio.

La idea de lucha por el acceso y distribución que viene implícita en el concepto de conflicto socioambiental es posible de identificar en el conflicto socioambiental del río Sambingo desde diferentes enfoques. El primero se refiere a los efectos ambientales que se expresan; a partir del cambio en las lógicas de relacionamiento con el río por parte de las poblaciones afrodescendientes, es decir, el río es visto en tanto espacio enajenado. Con esto se quiere decir, que ciertas actividades ya no son posibles de realizar, así, por ejemplo, los niños y adultos que habitan las partes bajas del drenaje no pueden bañarse en el río, tampoco pueden en tanto actividad complementaria de la dieta, dedicarse a la pesca. De tal suerte que, el río como eje articulador y estructurante de su espacio cultural e identidad territorial, ha sido desplazado al terreno de lo otro. Esto sería resultado de la acción de sujetos, con prácticas morales distintas a quienes históricamente han habitado el Sambingo.

Lo anterior conecta la idea de conflicto socioambiental con el principio de sustentabilidad. Es decir, analíticamente es posible afirmar desde dicho principio, que el sistema socioeconómico y las prácticas ético-ambientales sobre las cuales estaba estructurada la extracción de oro en el río Sambingo generó afectaciones en la base natural de los ecosistemas que hacían insostenible en términos ecológicos el desarrollo de esta actividad de manera permanente. Precisamente, es esta insostenibilidad espacial y temporal que genera importantes problemas morales, lo que hace necesaria a la ética ambiental (Marcos, 1999).

La Figura 3 es reveladora con relación a ello. Estos son algunos de los cráteres formados por el accionar de los sujetos que usan las retroexcavadoras. De esto es posible afirmar, que en este conflicto socioambiental la distribución ecológica, que resulta útil para articular diversidad, conflicto e igualdad en el acceso a recursos naturales, lo cual a su vez debe realizarse a través del nexo entre perspectivas culturales, económicas y ecológicas (Escobar, 2005), entra en disputa con el principio de la sustentabilidad y en términos más generales con la justicia ambiental. Su choque, no es analítico, sino práctico, pues ambas resultan insuficientes para pensar escenarios en los que la distribución y localización de bienes y males ambientales entre seres vivos se presente de forma justa. En el río Sambingo, la sustentabilidad, esto es la viabilidad ecológica, fue destruida por individuos racionales con prácticas morales que afectaron seriamente al ecosistema del río y a las poblaciones (humanas y no humanas) que se beneficiaban de él. 
Figura 3. Cráteres en el Río Sambingo 2016
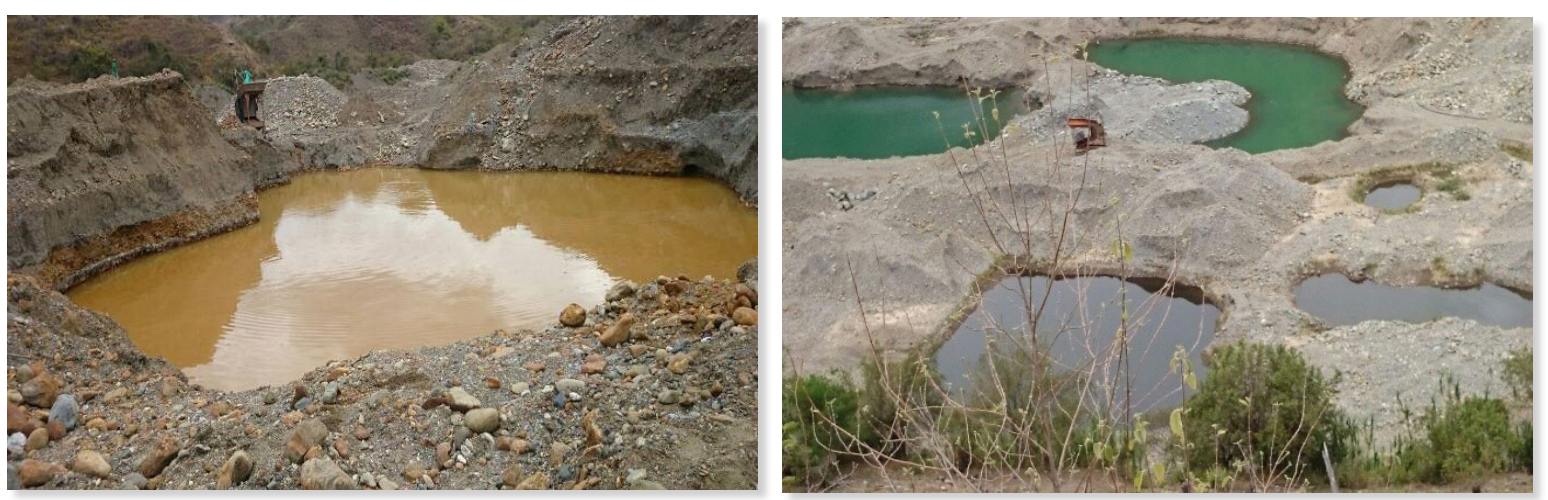

Fuente: CRC (2016b)

Los conflictos socioambientales se desenvuelven entre la necesidad de la sustentabilidad, especialmente los desarrollados en condiciones de legalidad, aunque no siempre, y los que requieren el terror para su desarrollo. La extracción de oro en el río Sambingo, pronto necesitó estas últimas características. La defensa que había sostenido un consejo comunitario de la zona buscaba la protección del río, el territorio y la vida. Es decir, de la distribución ecológica y de la sustentabilidad que les garantizaba en su espacio cultural que el río estuviese sin minería ilegal mecanizada. Sin embargo, esta actividad, no solo desarmonizó dinámicas político-organizativas, ecológicas, económico-productivas y socioculturales, sino que configuró esta área como una geografía del terror (Oslender, 2008). Ellas se instauran, como consecuencia de la ilegalidad que implicó la extracción de oro. De esta forma, se establecen unas territorialidades en las que se restringe la movilidad y las prácticas espaciales rutinarias de la población afrocolombiana. En palabras de Oslender (2008), esto se presenta cuando:

La implantación de un régimen de terror en un lugar supone restricciones en los movimientos cotidianos de la población. Éstas pueden ser explícitamente impuestas por los actores (...) que prohíben a la población local ir a ciertos lugares; o pueden ser implícitas, dictadas por el miedo y un sentido de terror que le aconseja a uno no moverse a ciertos lugares. Un sentido de inseguridad generalizado se extiende por el lugar $y$ afecta las formas en que la gente se mueve en sus alrede- dores. El contexto de terror lleva así a una fragmentación del espacio y rompe dramáticamente la movilidad espacial cotidiana. Bajo su régimen, frecuentemente las poblaciones locales están confinadas en ciertas áreas de las que no pueden salir. (Oslender, 2008, s/p)

En consecuencia, y siendo coherente con lo sostenido hasta aquí, la presencia de actores sociales que desarrollan actividades ilegales en el río Sambingo, ha generado una transformación del sentido de lugar para la población del área de estudio (Oslender, 2008). Este concepto se refiere a las:
(...) percepciones individuales y colectivas que se generan en él, y a los sentimientos asociados in- dividual y colectivamente. El nuevo contexto de terror dramáticamente transforma este sentido de lugar. Las personas empiezan a sentir, pensar y hablar de su lugar de vida de manera distinta, en formas ahora impregnadas de experiencias $y$ memorias traumáticas, y de miedos y angustias. (Oslender, 2008, s/p)

Los grandes despliegues militares realizados para tener control por parte del Estado de esta zona, así como las capturas realizadas por parte de la Policía de Colombia evidencia que las actividades eran desarrolladas por "una 'estructura criminal' que extraía unos cuatro kilos de oro cada diez días" (Semana, 07/04/2016). De hecho, durante estos operativos se capturaron en diferentes ciudades de Colombia a 14 personas vinculadas a la extracción de oro en esta zona y que tendrían que responder penalmente por "explotación ilícita de yacimiento minero, concierto para delinquir 
y financiación al terrorismo (...) también posibles casos de violencia sexual en los campamentos mineros" (El Colombiano, 06/04/2016). En definitiva, se puede afirmar con base en lo expresado en los reportajes periodísticos, que estos elementos dan lugar a que se presenten en la zona de estudio una interrupción radical de las prácticas y experiencias espaciales cotidianas, como consecuencia de las geografías del terror desplegadas.

En contraposición a esto, sostenemos que las poblaciones afrodescendientes asentadas en esta área presentan prácticas tradicionales de producción que no agotan la base de recursos sobre la cual se sustenta. Sin embargo, la llegada de agentes externos para la extracción del oro y la cantidad de dinero que circulaba, a partir de esta actividad, generó una serie de transformaciones, no solo en el paisaje cultural, sino también en los sujetos. Agricultores pasaron a ser barequeros, ganaderos a jornaleros, estudiantes a peones, entre otros.

En suma, podemos decir que son dos concepciones éticas de naturaleza completamente diferentes, y que la una absorbió a la otra. En la concepción de la gente afro, se puede establecer que su actuar hacia la naturaleza se relaciona con aquello que Leopold sostiene cuando expresa que solo "podemos actuar éticamente en relación con aquello que podemos ver, sentir, amar o de 'algún modo' tener fe" (Leopold, 2007 , p. 35). Su vínculo con la naturaleza les permitía sentirla, verla, y tenerle fe.

Tenemos entonces, que las acciones desarrolladas alrededor de la extracción de oro en el río Sambingo, configuran un conflicto socioambiental, en el cual la carga del impacto medioambiental negativo lo padecen las personas que históricamente han vivido allí, pues los que extraen el oro una vez terminan el desarrollo de sus actividades se marchan a otros lugares a continuar en la misma dinámica. Sumado a esto, el sistema de creencias, de valores de estas comunidades ha sido puesto en tensión. Al mismo tiempo, la extracción de oro en la zona no ha respetado los límites al crecimiento, y la capacidad de resiliencia del ecosistema se ha perdido, la cual es una condición necesaria incluso hasta para la reproducción misma de la cultura.
Para ir finalizando, desde el punto de vista analítico encontramos que un conflicto socioambiental, articula principios de sustentabilidad basados en la justicia ambiental, pero al mismo tiempo la noción de distribución ecológica. Esto se expresa en transformaciones del paisaje, sentidos de lugar y de apropiación del espacio.

Las miradas y prácticas que desarrollan estos dos agentes sociales, y la expresión de ello en la zona de estudio configuran luchas ontológicas que se sostienen en visiones del mundo y sistemas económico-productivos diferentes. Por ello resulta necesario llevar a la práctica una ética ambiental donde la intervención hacia la naturaleza esté guiada por buenas razones y no por la arbitrariedad. Esto definitivamente, implica una relación dialógica y argumentativa por parte de los diferentes actores sociales; exigencia de la igualdad y simetría en la búsqueda de consensos; reprobación de todo tipo de crueldad hacia las diversas expresiones de vida (Etxeberria, 1994), que son en última instancia, una de las posibilidades para llevar a la práctica y no en tanto imaginación teórica, el principio de sustentabilidad, en el que se basa la justicia ambiental.

\section{GeOGRAFÍA DEL EXTRACTIVISMO: REFLEXIONES EN} TORNO A LA MINERÍA EN EL RÍO SAMBINGO

Los siguientes resultados cartográficos nos sirven para reafirmar lo sostenido, pues se logra visualizar, a partir de las imágenes satelitales, dos momentos que expresan realidades diferentes. Junto con ello, presentamos los datos de las necesidades básicas insatisfechas a nivel rural en las dos municipalidades más afectadas en términos socioambientales por la extracción minera. En el mapa se aprecia que la imagen correspondiente al año 2014, no presentaba conflictos mineros aparentes. Una de las explicaciones de esto, es que para esas épocas el consejo Comunitario de Fe y Esperanza del corregimiento de Cajamarca-Mercaderes había logrado mantener a distancia de esta zona a los mineros, logrando incluso sacar a algunos de su territorio. Sin embargo, para 2015 y con las amenazas a líderes comunitarios, restricciones en la movilidad de la 
gente, los mineros se lograron posesionar en esta zona. En este sentido, la primera imagen visualiza formas de estar, pensar y luchar en la defensa del territorio, sino también en las formas en que políticamente los afrocolombianos se involucran con su territorio o espacio de vida (Figura 4).

Para el año 2016 se puede apreciar la presencia de nueve piscinas -en realidad eran muchas más a lo largo del cauce, pero usamos estas en tanto muestra-, en donde algunas tienen hasta $2.235 \mathrm{~m} 2$. En resumen, las piscinas clasificadas que representan un muestreo mínimo del total que hay en el cauce del río, corresponden en total a $14.562 \mathrm{~m} 2$. De lo anterior, nos interesa destacar que es el reflejo de dos ontologías diferentes. La imagen primera, la interpretamos en tanto experiencia de prácticas de las poblaciones afrodescendientes históricamente asentadas ahí y que expresan, siguiendo a Escobar (2015) mundos u ontologías relacionales, en palabras del académico colombiano esto se refiere a una:

(...) densa red de interrelaciones y materialidad a la que llamamos "relacionalidad" u "ontología relacional" (...) una ontología relacional puede definirse como aquella en que nada (ni los humanos ni los no humanos) preexiste las relaciones que nos constituyen. Todos existimos porque existe todo. (Escobar, 2015, p. 29)
En contraposición a la primera imagen, la segunda es configurada a partir de una ontología dual, basada en la separación de espacio/tiempo, naturaleza/cultura, mente/cuerpo, nosotros/ellos, oriente/occidente, lo que está llevando a la "erosión sistemática de la base ontológica-territorial de muchos otros grupos sociales, particularmente aquellos donde priman concepciones del mundo no dualistas, es decir, no basadas en las separaciones ya indicadas" (Escobar, 2015, p. 29).

Estas luchas por el acceso a recursos naturales y el agotamiento de la base biofísica de los ecosistemas en la que se sustentan estos, en el contexto que estamos haciendo esta investigación, se expresan más en los espacios rurales. Los siguientes datos, que si bien no hacen referencia al periodo estudiado nos permiten realizar una lectura general del por qué en las poblaciones afrodescendientes asentadas en el área de influencia del río, los efectos de la extracción de oro son mayores. El índice de necesidades básicas insatisfechas rural (NBI rural) en los municipios por donde pasa el cauce de este drenaje, desde el área donde comienza la extracción ilegal de oro, y que fueron afectados por esta extracción presentan los siguientes porcentajes como se puede apreciar en la Tabla 1:

Figura 4. Efectos de minería ilegal periodo 2014-2016

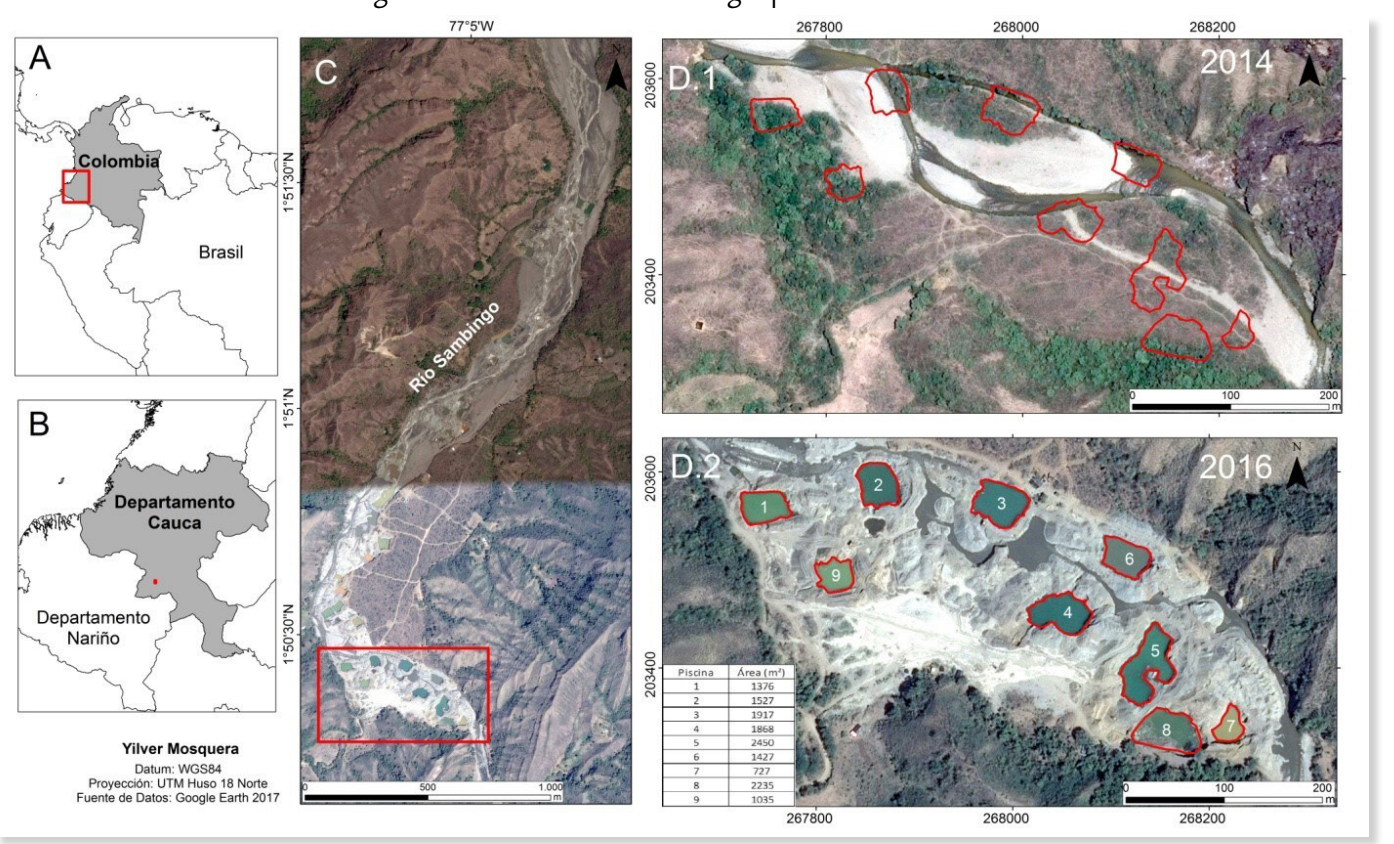

Fuente: elaboración personal con base en Google Earth (2017) 
Tabla 1. Índice de Necesidades básicas Insatisfechas Rural por municipio

\begin{tabular}{lr}
\hline \multicolumn{1}{c}{ Municipio } & \% NBI RURAL \\
\hline Bolívar & $72.78 \%$ \\
\hline Mercaderes & $79.96 \%$ \\
\hline Patía & $43.18 \%$ \\
\hline
\end{tabular}

Fuente: DANE (2012)

Estos datos nos indican que los niveles de pobreza son elevados, por lo tanto, debemos asumir que son comunidades vulneradas socialmente, en parte debido a la escasa presencia del Estado en estos territorios. Ello ha generado en la gente que habita esta zona y su área de influencia que las afectaciones, como consecuencia de la extracción ilegal de oro se sientan con más fuerza, de ahí que aumentaran el alcoholismo, la prostitución y la delincuencia organizada, entre otros elementos como parte de esos fenómenos que se derivan de las lógicas extractivistas ilegales.

Este conflicto socioambiental ha alterado radicalmente los estados de las naturalezas y al mismo tiempo ha afectado la cotidianidad de los habitantes locales. La extracción de oro se configura como una tecnología de despojo que dibuja nuevas espacialidades (Ojeda, 2017), tal como se pudo apreciar en la Figura 4. La esquilmación y la expoliación a la que se ve sometido este territorio, ha llevado a los habitantes locales a dinámicas de desterritorialización, entendida esta como la desactivación de linderos que tradicional e históricamente estas comunidades habían construido a partir de códigos culturales propios (Mosquera-VaIlejo, 2018; Mosquera-Vallejo, 2019). Restrepo (2017) analizó para el norte del Cauca, el proceso de extractivismo minero en esa región, y obtuvo conclusiones similares a las observadas en nuestra zona de estudio. Sostiene que:

Los nefastos efectos ambientales de las retros que destruyen la capa vegetal y la contaminación de los ríos con los sedimentos y el mercurio, es la dimensión ambiental del despojo de un entorno natural saludable para las poblaciones negras del norte del Cauca. La súbita presencia de grupos armados y de centenares de barequeros asociados a la minería ilegal, constituye una transformación socioespacial en términos de perdida de la autonomía y del territorio para las poblaciones negras de la región. (Restrepo, 2017, p. 10) (cursiva en el original)

Un proceso con dinámicas parecidas fue el que se vivió en el río Sambingo. La presencia -y ausencia- de múltiples actores sociales, supone diferenciados procesos de apropiación del territorio o territorialización (Haesbaert, 2011), que se inscriben y sedimentan a partir de disimiles prácticas materiales/simbólicas. La minería ilegal entonces, supone la re-invención de los territorios en tanto que se articulan en ella diferentes mecanismos de despojo que desarmonizan la vida cotidiana. Lo anterior, por ejemplo, nos lleva a reflexionar acerca de las transformaciones en los significados geográficos simbólicos/ materiales en relación con el río. Para las poblaciones negras de la zona de estudio, los ríos constituyen una especie de avenida, mediante la cual la gente se guía para ir de un lugar a otro. El río es el espacio donde se lava la ropa, cocina en fechas especiales, pesca para la complementación de la dieta alimentaria, también es donde el ganado bebe, los agricultores riegan sus cultivos, las personas se orientan río arriba o río abajo, hasta o desde el río, es decir, deviene en frontera. En el mismo sentido:

Dentro del sistema organizador e identificador, el río juega un papel central en todas las actividades económicas, domésticas y socio-culturales y es a la vez el factor principal de identificación en las zonas rurales (...) Además la gente viene al río a lavar la ropa, coger agua, y los niños a jugar. Estas actividades son de carácter casi ritual y están acompañadas por risas, cuentos y chismes (...) Referencias a lugares específicos y distan- 
cias también están relacionadas con el contexto acuático. Es común escuchar expresiones como "más arriba" y "más abajo" para describir una localidad particular, o de hablar de "tres curvas más” al expresar la noción de distancia, otra vez refiriéndose al río. (Oslender, 1998, pp. 266-267)

El río es un espacio de interacción social cotidiano, en donde se configuran y articulan diferentes lenguajes y prácticas espaciales entre los habitantes locales, y que, desde la llegada de las retroexcavadoras para la extracción ilegal de oro, los significados simbólicos/materiales se han venido reescribiendo, lo que ha conducido a una transformación de las formas de usar, generar, percibir. En suma, de construir y vivir el espacio por parte de los pobladores del río Sambingo.

\section{CONSIDERACIONES FINALES}

A modo de reflexión consideramos que la extracción de oro ha generado un conjunto de problemáticas que afectan la vida social, cultural, económica y ecológica en las poblaciones afrodescendientes que habitan los municipios de Mercaderes y Patía en el departamento del Cauca, y que estas son transversales debido a que afectan las distintas dimensiones de su vida. Dicha extracción vista desde determinados marcos éticos nos conduce a una serie de interpretaciones que ofrecen diferentes miradas de la realidad. Entre esas lecturas o interpretaciones de lo real, se encuentra la necesidad de generar planteamientos y decisiones de largo alcance, las cuales deben ser asumidas por diferentes sectores de la sociedad civil.

Los usos utilitaristas de la naturaleza vienen enmarcados en el interés de generar acumulación en la menor cantidad de tiempo posible, sin tener en cuenta las consecuencias ambientales, sociales, culturales que dichas intervenciones puedan tener. Es la necesidad de generar cambios frente a una situación adversa, la que nos debe llevar a tomar en serio la ética en tanto práctica y la justicia ambiental a través de la distribución ecológica. Se considera que a partir de estos enfoques disciplinares y posturas teóricas, es posible pensar críticamente determinados procesos que afectan a sectores vulnerables de la población. De hecho, y profundizando en el principio de sustentabilidad de la justicia ambiental, este nos lleva a pensar en el mañana, es menester a las próximas generaciones dejarles un mundo tan habitable, como históricamente lo han hecho las comunidades que habitan los espacios rurales, como los indígenas, campesinos y afros a sus descendientes. Para llegar a esto precisamos, superar el "subjetivismo moral de matriz antropocéntrica (...) El sujeto moderno precisa de ser purgado en lo que tiene de individualismo egocéntrico en la relación individuo-sociedad, pero también en lo que tiene de egoísmo utilitarista en la relación hombre-naturaleza" (Gómez Heras, 2005, p. 31).

A raíz de la publicación en la revista Semana, los efectos ambientales resultado de la minería ilegal generaron un cambio en la escala del conflicto socioambiental, pues dejó de ser esta una práctica moral invisible o localizada en un ámbito concreto del río, cuyo interés en la recuperación del río era solamente de algunos actores sociales de la zona, para configurarse en una práctica moral visible deslugarizada (Mosquera-Vallejo, 2020), pues las imágenes fueron lo suficientemente impactantes para que las autoridades tomaran cartas en el asunto. Sin embargo, una parte del cauce del río fue secado, pero es probable que una vez vuelvan las lluvias el agua va a volver, pero los peces que eran un componente de la base de la dieta alimentaria no estarán. Las personas no se pueden bañar en el río y menos beber el agua. Lo mismo sucede con los animales domésticos, como reses y cerdos. Las imágenes solamente muestran los cráteres causados por las retroexcavadoras, pero no dice mucho en relación con las problemáticas que se han producido. A nuestro modo de ver, también se han generado cráteres que erosionan prácticas tradicionales de producción, y ellas se encuentran ligadas a procesos de conocimiento local, sistemas de vida, que se asocian con formas de usar, generar y percibir el espacio.

Finalizamos esta reflexión con la idea de 
Leopold, en donde establece que es inconcebible que pueda existir una relación ética con la tierra sin amor, respeto y admiración por ella, y sin un gran aprecio por su valor.

\section{AgradeCIMIENTOS}

Esta investigación ha sido financiada y apoyada por la Beca que otorga la Comisión Nacional de Investigación Científica y Tecnológica (CONICYT) de Chile. Igualmente, nuestros agradecimientos a las geógrafas María Fernanda Anaya

\section{REFERENCIAS}

Arriaga, A, y Pardo, M. (2011). Justicia ambiental. El estado de la cuestión. Revista Internacional de Sociología, 69(3), 627-648.

Bellmont, Y. (2012). El concepto de Justicia Ambiental: reflexiones en torno a la jurisprudencia constitucional colombiana del siglo XXI. Tesis de maestría en Programa de Medio Ambiente y Desarrollo, Universidad Nacional de Colombia, Colombia.

De Cózar, J. (2005). Principio de precaución y medio ambiente. Revista Española de Salud Pública, 79(2), 133-144.

Departamento Nacional de Estadística (2010). Indice de Necesidades Básicas Insatisfechas Rural en el Departamento del Cauca. Sistema de información Geográfica para la Planeación y el Ordenamiento Territorial. Recuperado de http://sigotn.igac.gov. co/sigotn/default.aspx (consulta julio de 2017).

Environmental Law Alliance Worldwide E.L.A.W. (2010). Guía Para Evaluar ElAs de Proyectos Mineros. Recuperado de https://www.elaw.org/ files/mining-eia-guidebook/Guia\%20\%20 para\%20Evaluar\%20EIAs\%20de\%20Proyectos\%20Mineros.pdf (consulta julio de 2019)

Escobar, A. (2005). Depois da Natureza - Passos para uma Ecologia Política antiessencialista (pp. 17-55). En C. Parreira y H. Alimonda (Eds.) Políticas Públicas Ambientáis Latinoamericanas. Brasilia: Abaré/Flacso.

Escobar, A. (2015). Territorios de diferencia: la ontología política de los "derechos al territorio". Cuadernos de antropología social, 25-38.
Por valor nos referimos, obviamente, a algo mucho más amplio que el mero valor económico, nos referimos al valor en el sentido filosófico (Leopold, 2007).

Chamorro del IGAC-Colombia, y Yoshy Luengo Oyarzun de la Pontificia Universidad Católica de Chile, por colaborarnos en la elaboración de la cartografía temática, que visualiza localización y parte de los resultados del análisis.

Etxeberria, X. (1994). La ética ante la crisis ecológica. Cuadernos Bakeaz, 1-16.

Gómez-Heras, J. (2005). Ética y medio ambiente. La descomposición de la razón práctica. Isegoria, (32), 63-94.

Gudynas, E. (2010). Agropecuaria y nuevo extractivismo bajo los gobiernos progresistas de América del Sur. Territorios, 5, 37-54.

Haesbaert, R. (2011). El mito de la desterritorialización del "fin de los territorios" a la multiterritorialidad. México D.F: Siglo XXI Editora Iberoamericana. Hervé, D. (2010). Nociones y elementos de la justicia ambiental. Directrices para su aplicación en la planificación territorial y en la evaluación ambiental estratégica. Revista de derecho, XXII(1), 9-36.

Lecaros Urzúa, J. (2013). La ética medio ambiental: principios y valores para una ciudadanía responsable en la sociedad global. Acta bioethica, 19(2), 177-188.

Leff, E. (2003). La ecología política en América Latina: un campo en construcción. Sociedade e Estado, 18(1-2), 17-40.

Leopold, A. (2007). La ética de la tierra. Revista Ambiente y Desarrollo, XXIII, 29-40.

Marcos, A. (1999). Ética ambiental. Universitas Philosophica, (33), 31-57.

Marcos, A. (2011). Principio de precaución un enfoque (neo) aristotélico. Valladolid: Universidad de Valladolid.

Martínez-Alier, J. (2002). The environmentalism of 
the poor: A study of ecological conflicts and evaluation. Johannesburgo: World Summit on Sustainable Development.

Mosquera-Vallejo, Y. (2018). Escalas geográficas e identidades territoriales: trayectorias desde las comunidades negras del valle del $\mathrm{Pa}$ tía. Geographia Meridionalis, 4(2), 126-144. DOI http://dx.doi.org/10.15210/gm.v4i2.14484

Mosquera-Vallejo, Y. (2019). Espacios expoliados, paisajes esquilmados: cambios en el paisaje del valle del Patía 1964-2014 (pp. 90-123). En D. Santana-Rivas, V. Alvarado-Peterson y R. Hidalgo-Dattwyler (Eds.) Las geografías del neoliberalismo en América del Sur. Ensayos descriptivos, críticos y necesarios. Santiago de Chile: Serie Geolibros.

Mosquera-Vallejo, Y. (2020). Escala geográfica: visibilidades e invisibilidades en procesos culturales afrodescendientes (suroccidente de Colombia). Revista CS, (30), 251-276. DOI https://doi.org/10.18046/recs.i30.3330

Muradian, R.; Martinez-Alier, J. y Correa, H. (2003). International capital versus local population: The Environmental Conflict of the Tambogrande Mining Project, Perú. Society and Natural Resources, 16(9), 775-792.

Ojeda, D. (2017). Los paisajes del despojo: propuesta para un análisis desde las reconfiguraciones socioespaciales. Revista Colombiana de Antropología, 52(2), 19-44.

Oslender, U. (1998). Espacio e identidad en el pacífico colombiano: perspectivas desde la costa caucana. Cuadernos de Geografía: Revista

\section{OTRAS FUENTES}

Consejo Comunitario Fe y Esperanza. (2016). Carta al presidente Juan Manuel Santos Calderón. Inédito. 1-3. Mercaderes.

Corporación Autónoma Regional del Cauca -C.R.C. (2016a). Informe Técnico en atención a acciones de Protección y Vigilancia de los Recursos Naturales y el Ambiente, acción de oficio valoración ambiental a la zona de influencia del rio Sambingo en el municipio de Mercaderes, por extracción ilegal de oro. Inédito. 1-28. Popayán.
Colombiana de Geografía, 7(1-2), 251-290.

Oslender, U. (2008). "Geografías del terror": un marco de análisis para el estudio del terror. Scripta Nova. Revista Electronica de Geografía y Ciencias Sociales, XII(270). Recuperado de http://www.ub.edu/geocrit/sn/sn-270/sn-270144.htm (consulta en junio de 2017).

Riechmann, J. (2003a). Tres principios básicos de Justicia Ambiental. XII Congreso de la Asociación Española de Ética y Filosofía Política. Castellón.

Riechmann, J. (2003b). Tres principios básicos de justicia ambiental. Revista Internacional de Filosofía Política, (21), 103-120.

Restrepo, E. (2013). Etnización de la negridad: la invención de las "comunidades negras" como grupo étnico. Popayán: Editorial Universidad del Cauca.

Restrepo, E. (2017). Afrodescendientes y minería: tradicionalidades, conflictos y luchas en el norte del Cauca, Colombia. Vibrant: Virtual Brazilian Anthropology, 14(2). DOI https://dx. doi.org/10.1590/1809-43412017v14n2p225

Spadoni, E. (2017). Initiative for Peace Building. Recuperado de http://www.ifp-ew.eu/index.php (consulta julio de 2017).

Walter, M. (2009). Conflictos ambientales, socioambientales, ecológico distributivos, de contenido ambiental. Reflexionando sobre enfoques y definiciones. Boletín ECOS, 6, 1-9. CIP-ECOSOCIAL.

Zuluaga, F. (1993). Guerrilla y sociedad en el Patía. Cali: Editorial Facultad de Humanidades. Universidad del Valle.

Corporación Autónoma Regional del Cauca -C.R.C.- (2016b). Informe Técnico en atención a acciones de Protección y Vigilancia de los Recursos Naturales y el Ambiente, como acción de oficio al rio Sambingo, corregimiento de Cajamarca, municipio de Mercaderes, por extracción ilegal de minerales. Inédito. 1-10. Popayán.

Departamento Nacional de Estadística -D.A.N.E.- (2012). Necesidades Básicas Insatisfechas - NBI, por Total, Cabecera y Resto, según 
Departamento y Nacional. Recuperado de https://www.dane.gov.co/index.php/estadisticas-por-tema/pobreza-y-condiciones-de-vida/ necesidades-basicas-insatisfechas-nbi (consulta julio de 2017)

El Colombiano (06/04/2016). Caen más responsables de secar el río Sambingo. Recuperado de http:// www.elcolombiano.com/colombia/mineros-ilegales-desaparecieron-el-rio-sambingo-en-cauca-ID3894659 (consulta julio de 2017).

Pedro, líder afrodescendiente. Entrevista en el corregimiento El Pilón, Mercaderes, departamento del Cauca, 03 de julio de 2018.

Semana (29/01/2016). El primer río en Colombia que desaparece por completo. Recuperado de https://www.semana.com/nacion/articulo/fenomeno-de-el-nino-se-seca-el-primer-rio-encolombia/458485 (consulta julio de 2016).

Semana (07/04/ 2016). 14 detenidos acusados de secar el río Sambingo en Cauca. Recuperado de https://sostenibilidad.semana.com/ medio-ambiente/articulo/14-detenidos-acusados-de-secar-el-rio-sambingo-en-cauca/34860\#: :text=14\%20 detenidos $\% 20$ acusados\%20de\%20secar\%20 el\%20r\%C3\%ADo\%20Sambingo\%20 en 20 Cauca,a\%20 secar\%20el\%20r\%C3\%ADo\%20Sambingo. (consulta julio de 2018).

Yilver Mosquera-Vallejo es geógrafo de la Universidad del Cauca, Colombia y Candidato a Doctor en Geografía en la Pontificia Universidad Católica de Chile. Actualmente cuenta con una beca de la Agencia Nacional de Investigación y Desarrollo -ANID- para el desarrollo de su investigación doctoral. Sus líneas de investigación y publicaciones se han orientado a los procesos de construcción de territorio en poblaciones negras en Colombia, geografía histórica, geografía cultural y teoría de la escala geográfica. Actualmente está desarrollando su tesis doctoral, y es líder de la experiencia A Ciencia Cierta Eco 2018 "Aprendiendo a través del territorio: experiencias socioecológicas en la vereda El Carmelito-Patía”, que busca la protección y defensa del bosque seco tropical en el valle del Patía, suroccidente de Colombia. Instituto de Geografía. Facultad de Historia, Geografía y Ciencia Política. Pontificia Universidad Católica de Chile. Avenida Vicuña Mackenna 4860, Macul, Santiago de Chile, Chile, yamosquera@uc.cl

Alex Paulsen Espinoza es Magíster en Geografía y Geomática y Candidato a Doctor en Geografía en la Pontificia Universidad Católica de Chile. Actualmente cuenta con una beca de la Agencia Nacional de Investigación y Desarrollo -ANID- para el desarrollo de su investigación doctoral. Sus líneas de investigación y publicaciones se han orientado a las luchas urbanas, vivienda, procesos de despolitización de las políticas urbanas y programas de vivienda y tecnocracia urbana. Actualmente desarrolla sus actividades de investigación doctoral y es parte del equipo de la Fundación Feman, la que nace al alero del Movimiento de Pobladores Ukamau para asesorar a las familias pobladoras que se encuentran en procesos de acceso a la vivienda. Instituto de Geografía. Facultad de Historia, Geografía y Ciencia Política. Pontificia Universidad Católica de Chile. Avenida Vicuña Mackenna 4860, Macul, Santiago de Chile, Chile, appaulse@uc.cl 